\title{
Uji Toksisitas Akut Ekstrak Etanol Daun Sapu Jagad (Isotoma longiflora (L) Presl.) pada Mencit Galur Mus muculus
}

$\operatorname{Ira~Safitri~}^{1}$, Inayah $^{2}$

\begin{abstract}
Sapu Jagad (Isotoma longiflora (L) Presl.) plant has been empirically used as traditional medicine. Some studies show that this plant has pharmacological effects as antibiotic, anticancer, and analgetic. It is of importance to conduct study in finding out the safetiness of this plant as herbal medicine. Therefore, we conducted study to find out lethal dose of its leaves on mice (Mus muculus) using acute toxicity test. Several doses have been given to certain groups to find out its effect including death. The extract has been given one time per oral. Then, we recorded the clinical signs and death of mice until 14 days. The data was analyzed using probit analysis to measure LD50. This study shows that ethanol extract of Sapu Jagad leaves has LD50 $12.610 \mathrm{mg} / \mathrm{kgBW}$ and toxicity of central nervous system proven by seizure ending with death. As conclusion, this extract has toxicity especially to central nervous system.
\end{abstract}

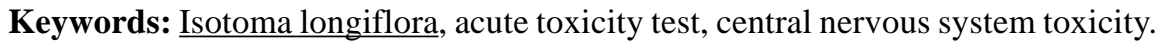

Tanaman yang digunakan secara tradisional di masyarakat untuk mengatasi berbagai penyakit termasuk kanker memerlukan penelitian mendalam untuk mengetahui kandungan dan khasiat, manfaat serta tingkat keamanannya. Salah satu tanaman yang biasa digunakan masyarakat di Indonesia dan akan diteliti adalah Isotoma longiflora (L) Presl. yang memiliki nama daerah antara lain Sapujagad di daerah Riau, Sangkobak di daerah Jawa, dan daun Tolod di daerah Sunda. ${ }^{1}$

Penelitian terakhir menunjukkan bahwa ekstrak metanol daun dan bunga Isotoma longiflora $(L)$ Presl.serta beberapa hasil fraksinasinya memiliki efek sitotoksik terhadap larva udang artemia salina berdasarkan metode Brine Shrimp Lethality Test (BSLT). Fraksi etil asetat dari daun dan bunga menunjukkan efek sitotoksik paling kuat. ${ }^{2}$ Penelitian lain mengenai kandungan kimia Isotoma longiflora (L) Presl. menunjukkan tanaman ini mengandung senyawa kimia, terpenoid, polifenol dan alkaloid. ${ }^{3}$

\footnotetext{
Penulis korespondensi: Bagian Farmakologi Fakultas Kedokteran Universitas Riau. J1.Diponegoro No.1, Pekanbaru.Email: irasafitri@yahoo.com

2 Bagian Farmakologi Fakultas Kedokteran Universitas Riau
}

Manfaat lain yang telah diteliti menunjukkan ekstrak batang dan beberapa fraksinya memiliki efek antimikroba terhadap bakteri Staphylococcus aureus begitu juga ekstrak daun dan beberapa fraksinya menunjukkan efek antimikroba terhadap bakteri Staphylococcus aureus dan bakteri Bacillus subtilis. ${ }^{3,4}$ Di Cina seluruh bagian tanaman dapat digunakan untuk pengobatan kanker, gigitan ular dan anestesi lokal. ${ }^{5}$

Tingkat keamanan suatu obat dapat diteliti dengan menentukan toksisitasnya. Toksisitas suatu zat adalah kemampuan suatu zat untuk menimbulkan kerusakan pada organisme hidup. Pada dasarnya, semua zat, bahan dan sediaan kimia baru yang akan digunakan pada manusia, hewan dan lingkungannya perlu diuji keamanannya, bila ada kemungkinan berbahaya untuk kesehatan. ${ }^{6}$

Salah satu uji toksisitas yang dapat dilakukan adalah uji toksisitas akut. Toksisitas akut adalah efek-efek merugikan yang timbul segera setelah pemberian dosis tunggal dari suatu zat atau pemberian dosis berulang dalam waktu 24 jam. Ada beberapa macam cara pemberian untuk pengujian toksisitas akut, yaitu secara oral, parenteral, inhalasi, kulit dan mata. Suatu indeks untuk mendefinisikan 
toksisitas akut dikenal dengan istilah Dosis Letal $50\left(\mathrm{LD}_{50}\right){ }^{7}$

Tanaman sapu jagad (Isotoma longiflora $(L)$ Presl.) secara taksonomi diklasifikasikan sebagai berikut .

$\begin{array}{ll}\text { Kingdom } & : \text { Plantae } \\ \text { Divisio } & : \text { Spermatophyta } \\ \text { Kelas } & : \text { Dicotyledoneae } \\ \text { Anak Kelas } & : \text { Sympetale } \\ \text { Bangsa } & : \text { Campanulatae (Asterales, } \\ & \text { Synandrae) } \\ \text { Famili } & : \text { Campanulaceae } \\ \text { Genus } & : \text { Isotoma } \\ \text { Spesies } & : \text { Isotoma longiflora }(\mathrm{L}) \text { Presl. }\end{array}$

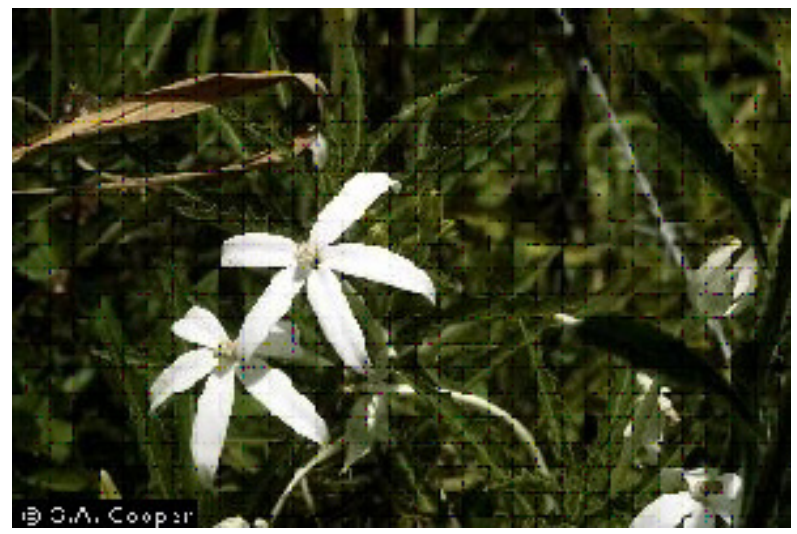

Gambar 1. Bunga dan Daun Isotoma longiflora (L) Presl. ${ }^{7}$

Penelitian ini dilakukan dengan tujuan untuk mengukur tingkat keamanan ekstrak etanol daun Isotoma longiflora (L) Presl. pada hewan coba (mencit) dengan menentukan $\mathrm{LD}_{50}$ dan melihat efekefek yang ditimbulkannya pada pemberian peroral dosis tunggal.

\section{METODE}

\section{Subjek penelitian}

Subjek penelitian ini adalah 30 ekor mencit jantan galur Mus muculus yang diperoleh dari bagian Farmakologi FK UNRI. Pada penentuan $\mathrm{LD}_{50}$ ekstrak etanol daun Isotoma longiflora (L) Presl mencit dikelompokkan secara acak dalam 5 kelompok, yang masing-masing terdiri dari minimal 5 mencit. Sebelum subjek penelitian dikelompokkan, semua mencit diberikan penyesuaian terlebih dahulu agar bisa beradaptasi dalam lingkungan Laboratorium Farmakologi FK UNRI selama satu minggu. Selama masa adaptasi tersebut, hewan coba diberikan makanan dan minuman secukupnya.

Kriteria inklusi adalah mencit sehat, bergerak aktif, berat badan awal $20-25$ gram, usia $2-3$ bulan. Kriteria eksklusi bila terjadi penurunan berat badan selama adaptasi $>10 \%$ atau mencit terlihat sakit. Bahan penelitian adalah ekstrak etanol daun Isotoma longiflora (L) Presl. Alat penelitian terdiri dari spuit $1 \mathrm{cc}$ dan $5 \mathrm{cc}$, selang sonde, botol minum mencit 12 buah, kandang mencit 12 buah, dan timbangan digital.

\section{Desain penelitian}

Penelitian ini adalah eksperimental laboratorium dengan teknik pengambilan sampel Rancangan Acak Lengkap (RAL). Pada penelitian ini dilakukan pemberian ekstrak etanol daun Isotoma longiflora (L) Presl pada mencit galur Mus muculus dengan rentang dosis tinggi untuk melihat kematian mencit sehingga dapat ditentukan nilai $\mathrm{LD}_{50}$ dari ekstrak etanol daun Isotoma longiflora (L) Presl.

\section{Prosedur penelitian}

Penelitian ini menggunakan mencit jantan galur Mus muсulus. Sebelum diberikan perlakuan, mencit dipuasakan selama 24 jam. Kemudian 30 ekor mencit untuk penentuan $\mathrm{DL}_{50}$ ekstrak etanol daun Isotoma longiflora (L) Presl masing-masing dikelompokkan secara acak kedalam 5 kelompok uji dan 1 kelompok kontrol (Masing-masing kelompok terdiri dari 5 ekor mencit). Tiap kelompok selanjutnya mendapat perlakuan yang berbeda sebagai berikut:

- Kontrol : 5 ekor mencit, diberi $1 \mathrm{ml}$ aquades

- Kelompok I : 5 ekor mencit diberi ekstrak etanol daun Isotoma longiflora (L) Presl yang telah dilarutkan dalam $1 \mathrm{ml}$ akuades dengan dosis (15 
$\mathrm{mg} /$ mencit) atau $750 \mathrm{mg} /$ $\mathrm{kgBB}$ peroral.

- Kelompok II : 5 ekor mencit diberi ekstrak etanol daun Isotoma longiflora (L) Presl yang telah dilarutkan dalam $1 \mathrm{ml}$ akuades dengan dosis $(150 \mathrm{mg} / \mathrm{mencit})$ atau 7500 $\mathrm{mg} / \mathrm{kgBB}$ peroral.

- Kelompok III : 5 ekor mencit diberi ekstrak etanol daun Isotoma longiflora (L) Presl yang telah dilarutkan dalam $1 \mathrm{ml}$ akuades dengan dosis (300mg/mencit) $15.000 \mathrm{mg} /$ $\mathrm{kgBB}$ peroral.

- Kelompok IV : 5 ekor mencit diberi ekstrak etanol daun Isotoma longiflora (L) Presl yang telah dilarutkan dalam $1 \mathrm{ml}$ akuades dengan dosis (600mg/mencit) $30.000 \mathrm{mg} /$ $\mathrm{kgBB}$ peroral.

- Kelompok V: 5 ekor mencit diberi ekstrak etanol daun Isotoma longiflora (L) Presl yang telah dilarutkan dalam akuades dengan dosis (1200mg/mencit) $60.000 \mathrm{mg} /$ $\mathrm{kgBB}$ peroral.

Setiap mencit pada tiap kelompok perlakuan, hanya diberikan ekstrak etanol daun Isotoma longiflora (L) Presl. satu kali. Sebagai pengamatan kontrol adalah hasil pengamatan pada waktu 0 jam. Setelah diberi perlakuan, dilakukan pengamatan terhadap gejala/efek yang muncul dan jumlah mencit yang mati sampai hari ke-14 setelah perlakuan.

\section{Analisis statistik}

Analisis data menggunakan program statistik probit, berdasarkan jumlah kematian mencit untuk masing-masing dosis ekstrak etanol daun sapu jagad untuk mengetahui nilai $\mathrm{LD}_{50}$ dan dilakukan pada batas kepercayaan $95 \%$.

\section{HASIL}

Penelitian yang dilakukan menunjukkan bahwa pada kelompok IV telah terjadi kematian pada seluruh hewan coba sehingga kelompok $\mathrm{V}$ dengan dosis lebih tinggi $(60.000 \mathrm{mg} / \mathrm{kgBB})$ batal dilakukan. Hasil uji toksisitas didapatkan sebagai berikut:

Tabel 1. Uji Toksisitas Ekstrak Etanol Daun Sapu Jagad

\begin{tabular}{lll}
$\begin{array}{l}\text { Dosis } \\
\text { (mg/kgBB) }\end{array}$ & $\begin{array}{l}\text { Efek } \\
\text { (kematian) }\end{array}$ & $\begin{array}{l}\text { Jumlah (hewan } \\
\text { coba) } \\
750\end{array}$ \\
0 & 1 & 6 \\
\hline 7500 & 6 & 6 \\
15000 & 6 & 6 \\
\hline 30000 & 6 & 6
\end{tabular}

Data di atas kemudian dilakukan perhitungan dengan analisis probit menggunakan Finney computer programme for probit analysis untuk menentukan $\mathrm{LD}_{50}$. Hasilnya didapatkan $\mathrm{LD}_{50}$ ekstrak etanol daun Sapu Jagad adalah 12.610,9 mg/kgBB dengan selang kepercayaan 0,05 dan Galat $\mathrm{LD}_{50}$ $4.437,499 \mathrm{mg} / \mathrm{kgBB}$. Hasil analisis probit tampak pada grafik berikut:

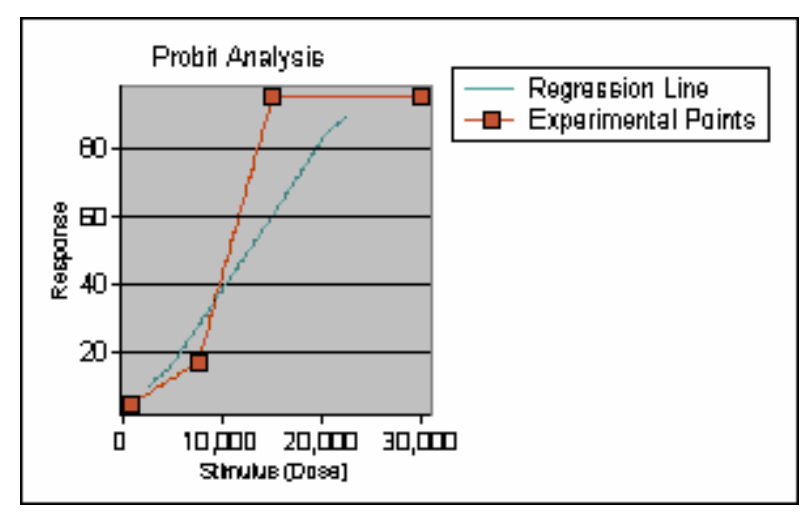

Gambar 2. Grafik Analisis Probit Uji Toksisitas

Keterangan : stimulus (dose) adalah dosis uji yang diberikan pada hewan coba dalam satuan $\mathrm{mg} /$ $\mathrm{kgBB}$. Response adalah jumlah hewan coba yang mati setelah pemberian ekstrak pada dosis tertentu dalam persentase $(\%)$.

Selanjutnya dilakukan perhitungan untuk melihat hubungan antara efek dosis terhadap respon (berupa waktu kematian) (Tabel 2 dan Gambar 3). Hasilnya didapatkan respon kematian tercepat 
terjadi pada kelompok IV (dosis 30.000) dengan kematian terjadi rata-rata dalam 10 menit setelah pemberian ekstrak etanol daun sapu jagad peroral. Selanjutnya diikuti oleh kelompok III dengan ratarata respon (berupa waktu kematian) terjadi dalam 53,33 menit setelah pemberian ekstrak dan kelompok II respon kematian terjadi dalam 1440 menit setelah pemberian ekstrak. Sedangkan pada kelompok I tidak terjadi kematian pada hewan coba sehingga waktu kematiannya setara dengan tak terhingga.

Tabel 2. Hasil penelitian Efek Dosis terhadap Respon (Waktu Kematian)

\begin{tabular}{|c|c|c|c|}
\hline \multicolumn{4}{|l|}{ Dosis 30000} \\
\hline $\begin{array}{l}\text { Waktu kematian } \\
\text { (menit) }\end{array}$ & $\begin{array}{l}\text { Respon } \\
\text { (mencit mati) }\end{array}$ & & $\begin{array}{l}\text { Rerata waktu kematian } \\
\text { (menit) }\end{array}$ \\
\hline (T) & (R) & TxR & $\sum \mathrm{TxR} / \Sigma \mathrm{R}$ \\
\hline 5 & 2 & 10 & \\
\hline 10 & 3 & 30 & \\
\hline \multirow[t]{2}{*}{20} & 1 & 20 & \\
\hline & 6 & 60 & 10 \\
\hline \multicolumn{4}{|l|}{ Dosis 15000} \\
\hline 120 & 2 & 240 & \\
\hline 30 & 1 & 30 & \\
\hline 20 & 2 & 40 & \\
\hline 10 & 1 & 10 & \\
\hline & 6 & 320 & 53.33333 \\
\hline \multicolumn{4}{|l|}{ Dosis 7500} \\
\hline 1440 & 1 & 1440 & 1440 \\
\hline
\end{tabular}

Dosis 750

Tak terhingga - Tak terhingga

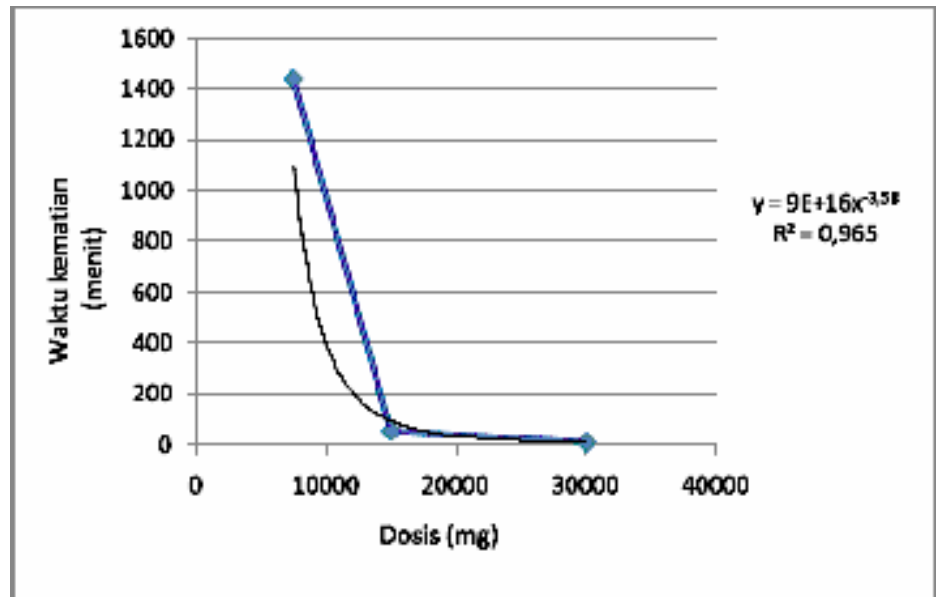

Gambar 3. Grafik Efek Dosis terhadap Respon berupa Waktu Kematian 


\section{PEMBAHASAN}

Hasil penelitian menunjukkan pada kelompok kontrol negatif seluruh mencit tampak berperilaku normal dan tidak ada mencit yang mati selama pemantauan (sampai dengan hari ke-14). Perilaku mencit pada kelompok kontrol menjadi dasar pembanding bagi kelompok perlakuan lainnya. Jika perilaku kelompok perlakuan tampak seperti kelompok kontrol maka pada dosis tersebut berarti tidak menimbulkan toksisitas.

Pada kelompok I dosis $(750 \mathrm{mg} / \mathrm{KgBB})$ tidak ada mencit yang mati dan seluruh mencit pada kelompok ini terlihat penunjukkan perilaku normal, tidak tampak tanda atau gejala adanya toksisitas, sama seperti pada kelompok kontrol, artinya pada dosis ini belum menimbulkan toksisitas.

Pada kelompok II dosis (7500 mg/KgBB) terlihat dua ekor mencit tampak menjadi diam/lebih tenang dibandingkan sebelum pemberian ekstrak terutama pada satu jam pertama untuk kemudian kembali terlihat normal beberapa jam berikutnya. Perbedaan perilaku sebagian mencit pada dosis ini menunjukkan mulai adanya efek pemberian ekstrak terutama pada Susunan Saraf Pusat (SSP), mungkin penekanan pada SSP walaupun hanya terjadi pada sebagian mencit dan dalam waktu singkat.

Pemantauan pada keesokan harinya setelah 24 jam pada kelompok II dosis $(7500 \mathrm{mg} / \mathrm{KgBB})$ tampak seekor mencit (mencit 1) yang hari sebelumnya terlihat diam sampai dengan jam kedua tapi setelahnya tampak normal ternyata sudah mati, sedangkan yang lain dalam kelompok yang sama terlihat berperilaku normal. Kematian mencit ini diduga akibat efek toksik dari pemberian ekstrak pada mencit tersebut.

Pada kelompok III dosis (15000mg/kgBB) 4 ekor mencit mati dalam satu jam pertama dan dua ekor mati dalam 2 jam. Seluruh mencit pada kelompok ini mengalami kematian dimana sebelumnya menunjukkan gejala yang sama yaitu diawali dengan terlihat bingung, diam, lemah, diikuti tremor kemudian kejang dan akhirnya mati. Gejala yang tampak pada setiap mencit sama, hanya waktu munculnya gejala pada tiap mencit terdapat perbedaan. Pada dosis ini tampak jelas efek toksik pemberian ekstrak pada SSP dan menimbulkan kematian pada seluruh hewan coba dalam dua jam setelah pemberian dosis uji.
Pada kelompok IV dosis $(30000 \mathrm{mg} / \mathrm{kgBB})$ seluruh mencit mati dalam satu jam pertama. Dua ekor mencit dalam 5 menit setelah pemberian tampak bergerak tak terkendali dan melompatlompat untuk kemudian kejang dan mati sedangkan empat ekor mencit lainnya tampak diam setelah pemberian kemudian diikuti tremor, kejang dan akhirnya mati hanya dalam 20 menit setelah pemberian ekstrak.

Gejala yang tampak pada kelompok III dan IV mungkin disebabkan oleh toksisitas berupa perangsangan berlebihan pada Susunan Saraf Pusat (SSP), terutama tampak dari timbulnya kejang dan juga gerakan motorik tak terkontrol pada mencit. Tanaman Isotoma longiflora (L) Presl mengandung diphenyl obediol yang merupakan stimulan SSP. ${ }^{8}$ Perbedaan yang menarik tampak pada kelompok II yang justru memperlihatkan gejala mencit menjadi tampak lebih tenang/ diam dalam 1-2 jam setelah pemberian ekstrak. Hal ini mungkin dikarenakan pada dosis rendah ekstrak tanaman sapu jagad bekerja menekan SSP sedangkan pada dosis tinggi menyebabkan stimulasi/perangsangan pada SSP.

Analisis statistik menunjukkan LD50 dari ekstrak Sapu Jagad adalah $12.610 \mathrm{mg} / \mathrm{kgBB}$ atau $12,61 \mathrm{gr} / \mathrm{KgBB}$ dengan selang kepercayaan (p: 0,05 ). Jika suatu zat memiliki LD50 antara $5-15 \mathrm{gr} /$ $\mathrm{kg}$ BB pada manusia dengan BB 70kg, maka zat tersebut dikategorikan sebagai slightly toxic, atau sedikit toksik. ${ }^{8}$ Berdasarkan gejala yang timbul, dan juga LD50 yang didapat, diduga ekstrak etanol tumbuhan Sapu Jagad memiliki efek toksik terutama pada SSP.

\section{KESIMPULAN}

Ekstrak etanol tumbuhan Sapu Jagad memiliki $\mathrm{LD} 50=12.610 \mathrm{mg} / \mathrm{kgBB}$, artinya tanaman ini tergolong memiliki toksisitas rendah (Slightly toxic). Perbedaan dosis uji menunjukkan pada dosis kecil (kelompok I) efek yang ditimbulkan berbeda dengan pada dosis besar (kelompok II dan III) dimana pada dosis kecil gejala yang muncul adalah mencit menjadi lebih tenang (penekanan pada SSP) dan dosis besar menimbulkan kejang (perangsangan berlebih pada SSP). Gejala yang timbul akibat pemberian ekstrak tanaman Sapu Jagad menunjukkan adanya efek toksik terutama pada SSP. 
Penelitian lebih lanjut mengenai mekanisme kerja ekstrak Sapu Jagad dalam menimbulkan toksisitas dan juga tingkat keamanannya terutama pada manusia sangat diperlukan agar tanaman ini dapat dikembangkan menjadi fitofarmaka.

\section{UCAPAN TERIMA KASIH}

Penulis mengucapkan terima kasih yang sebesar-besarnya kepada Fakultas Kedokteran Universitas Riau, Dra. Dasni Syafril, Apt, dr. Wiwik R Wirasto, M.Kes dan dr. Yessi, M.Kes atas segala fasilitas dan kemudahan yang diberikan kepada penulis selama melaksanakan penelitian ini.

\section{DAFTAR PUSTAKA}

1. Heyne K. Tumbuhan Berguna Indonesia III. Badan Penelitian dan Pengembangan Kehutanan, Departemen Kehutanan. Edisi ke1. Jakarta: Yayasan Sarana Wana Jaya; 1987. h. 1821.

2. Safitri I. Perbandingan Efek Sitotoksik Ekstrak Metanol serta Fraksi n-Heksan, Etil Asetat dan Metanol Daun dan Bunga Tanaman Sapu Jagad (Isotoma longiflora (L) Presl.) dengan Metode Brine Shrimp Lethality Test [tesis]. Bandung: Universitas Padjadjaran; 2008.
3. Safitri, I, Inayah, Hamidy Y, Dasni.S. Uji Aktifitas Antimikrobial Ekstrak Metanol Batang Tumbuhan Sapu Jagad (Isotoma longiflora (L) Presl.) [Laporan penelitian]. Pekanbaru: Lembaga Penelitian Univeristas Riau; 2005.

4. Hamidy Y, Safitri I, Inayah. Efek Antimikroba Ekstrak Metanol Daun Sapu Jagad (Isotoma longifolia) terhadap Escherichia coli. Jurnal Sains dan Teknologi Unila 2006; 12(2):91-6.

5. National Academy of Science. Herbal Pharmacology in The People's Republic of China;2000. Diakses dari: http:// www.swsbm.com.

6. DiPasquale LC, Hayes AW. Acute Toxicity and Eye Irritancy in Principles and Methods of Toxicology.4th Ed. Philadelphia:Taylor and Francis; 2001.p.853-855.

7. Cooper GA. Smithsonian Institution, Department of Systematic Biology-Botany. United States, HI, Kauai, Anini Beach County Park.Diakses dari: http://plants.usda.gov/

8. Eduardo Q. Medical Plants of The Philippine. Quezon City:JNC Press, Inc;1978. p.953-4. 